\title{
USE OF GRAPHIC CORRELATION FOR ASSESSING EVENT-STRATIGRAPHIC SIGNIFICANCE AND trans-ATLANTIC RELATIONSHIPS OF ORDOVICIAN K-BENTONITES
}

More than 60 separate volcanic ash beds, generally referred to as K-bentonites, are known from Ordovician successions within a more than 1 million $\mathrm{km}^{2}$ large area in North America that extends from the eastern Appalachians westwards to Iowa and Minnesota. Ordovician K-bentonites occur in an even larger area in Europe from the British Isles to eastern Baltoscandia and Poland. The largest number of individual beds recorded is in Scania, southernmost Sweden where close to 200 beds have been recognized. A volcanic eruption lasts a very brief time geologically and an ash bed represents as close an approximation of a regionally distributed time-plane as one is likely to find in nature. Hence K-bentonites have great potential as event-stratigraphic markers, provided individual beds can be traced laterally with confidence. Based on horizontal tracing and on biostratigraphy, individual beds have been used for local and regional correlations both in North America (Kay, 1935; Bergström, 1982) and Europe (Bergström, Nilsson, 1974). A recent advance is using chemical fingerprinting techniques for tracing single beds regionally (see, for instance, Kolata et al., 1986).

The present study is an attempt to assess the biostratigraphic and event-stratigraphic significance of individual K-bentonite beds, as well as complexes of beds, by means of conodont-based graphic correlation techniques as well as more conventional conodont and graptolite biostratigraphy. Extensive recent studies, particulary those involving nonbenthic fossils, have led to considerable refinement of the Ordovician biostratigraphy in North America. For instance, the Graphic Correlation Composite Standard Section (CSS) established for the upper Middle and Upper Ordovician by Sweet $(1984,1988)$ has a conceptual resolution of about 462,000 years. Although in some cases the resolution in practice is likely to be somewhat lower, the use of this method makes it possible to define the stratigraphical position of individual K-bentonite beds in terms of CSS units in graphically correlated sections with a previously unobtainable precision. This provides us with a new insight into the K-bentonite bed distribution patterns in time and space not only in North America but also in northwestern Europe. The present contribution summarizes some highlights from my ongoing studies in this field but space limitations make it necessary to postpone publication of a large amount of data used in this research.

\section{North America}

The vast majority of the North American Ordovician K-bentonites occur in the upper Middle and lower Upper Ordovician (upper Chazyan through lower Edenian). Only two older occurrences are known to me, 


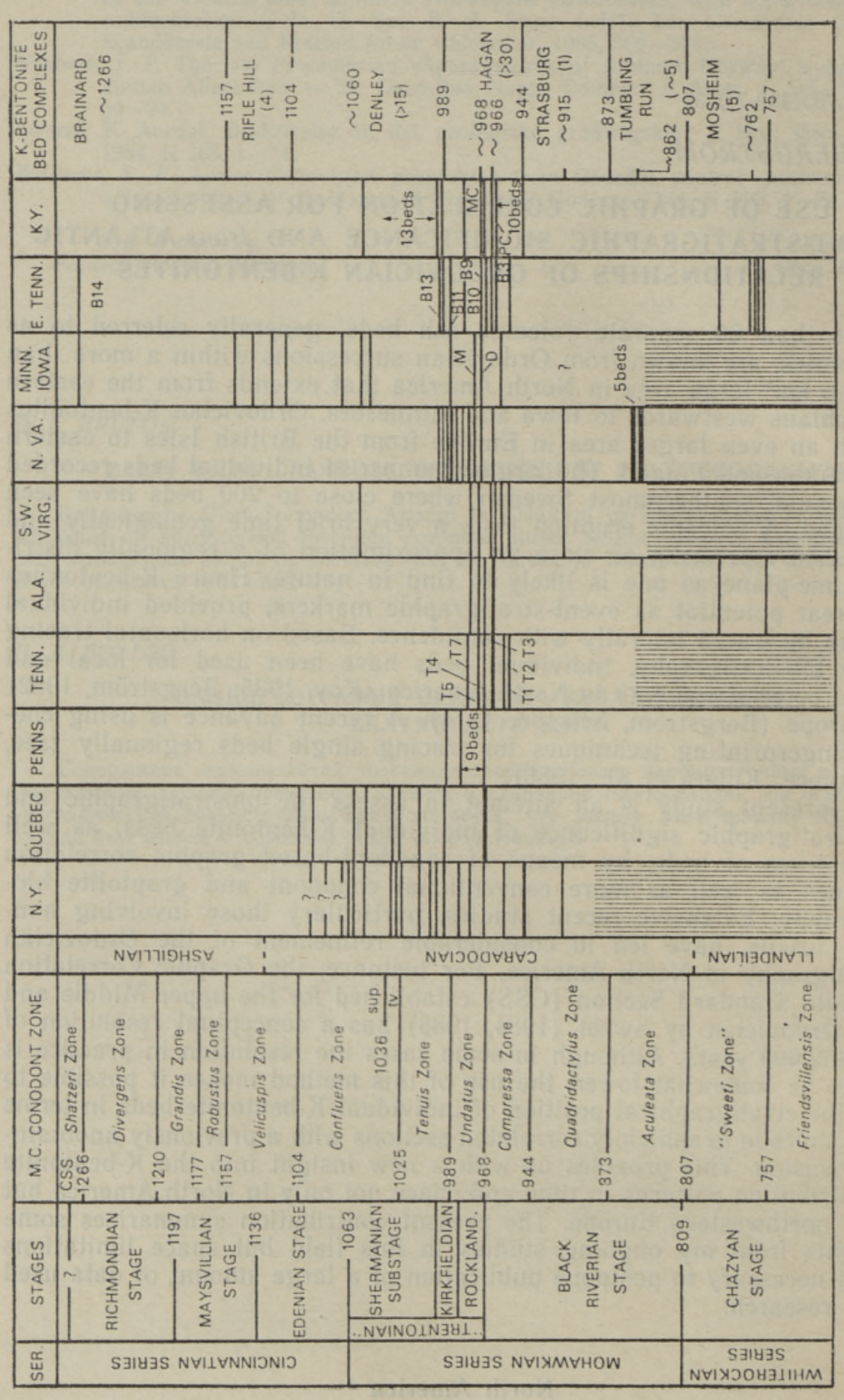

实 3

맘

tos

焉考

o.

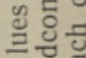

政

in $\equiv$

U.

ฮึ่

은

E.등

임

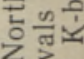

Z

.

s. =

ฮㄴ.

w言

고융요

돈

흥

उ 5

뭉

O음

등

น

든.

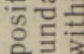

nᄋ

บ믈

of

을

这

.

은

-

용

E

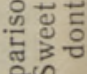

官

웛

-i

的资 
one from western Newfoundland (three beds in the Llanvirnian; Finney, Skevington, 1979) and one in eastern Tennessee (probably Llanvirnian; Laurence, 1944). As shown in the summary diagram (Fig. 1), K-bentonite beds are also quite rare in the uppermost Ordovician, being known from just a few localities.

There are K-bentonites in several of the sections included in Sweet's $(1984,1988)$ CSS and the position of these can be readily defined in terms of CSS units. In the case of sections not included in the CSS at the time being, traditional conodont biostratigraphy can be used to locate Sweet's CSS-defined zonal boundaries, and K-bentonite levels expressed in CSS divisions can then be established by interpolation. Obviously, there will be an error using this procedure but it is probably less than 10 CSS units in most cases.

Some conspicuous, geographically widespread, and much studied K-bentonite beds such as the Deicke (D) and the Millbrig (M) have received geographical names to facilitate reference but it is clearly both inappropriate and impossible to name each of the dozens of beds present in some sections. However, many, if not most, beds tend to occur in bed complexes within definable stratigraphic intervals, and for convenience of reference, seven such complexes are named and defined in terms of CSS units in Fig. 1. The number of beds in each complex varies from one (Brainard) to more than 30 (Hagan). As shown in Fig. 1, the preservation of individual beds, or bed complexes, varies greatly geographically and this is believed to be mainly a function of conditions in the depositional environment although it cannot, of course, be ruled out that some of the ash falls did not reach all parts of eastern North America because of prevailing winds and other factors. It is, however, clear that the low-energy deeper-water dark shale successions in New York contain more K-bentonite beds than the coeval higher-energy shallower-water carbonate sequences in Alabama and Pennsylvania. Obviously, the unusually thick and widespread beds, such as the Deicke and the Millbrig, have the greatest potential as regional event-stratigraphic markers but as suggested by Fig. 1, several thinner, stratigraphically more or less isolated, beds may prove to be equally useful, at least locally. Yet the distribution of such relatively inconspicuous beds remains poorly known regionally, and much additional study is needed to assess their significance.

\section{Comparison with Baltoscandia}

The vertical-distribution pattern of Ordovician K-bentonites in Baltoscandia exhibits a rather striking general similarity to that of eastern North America in having a marked concentration of beds in the upper Middle Ordovician (including the presence of two unusually thick beds) and the presence of only single beds in the Upper Ordovician. A significant difference is that 30 beds are known from the Arenigian and Llanvirnian of south Sweden (Fig. 2) whereas only a few beds are known from the North American Llanvirnian and none from the Arenigian. It should be noted, however, that this stratigraphical interval is not well represented regionally in eastern North America due to the Whiterockian regression, and when rocks of this age are present, in most cases their facies is not very favourable for the preservation of volcanic ash beds.

Because Sweet (1984) defined the level of some of the North Atlantic conodont zone boundaries in terms of CSS units, these CSS levels can be transferred directly into the succession in Baltoscandia, and the position of K-bentonite beds established, at least approximately, in CSS units by interpolation based on stratigraphic thickness between defined levels. 
activity in a common source area in the northern Iapetus but additional studies are needed to clarify whether or not some of the ash falls are likely to have originated from the same eruptions. Be that as it may, these ash falls are certainly among the largest known in the Earth's history, in all probability significantly larger than the recently much discussed dust clouds proposed associated with the terminal Cretaceous extinction event. In view of this, it is of interest to note that the regional effects of the Ordovician ash falls on the preservable portion of the organism world appear to have been relatively modest without global extinction events.

\section{REFERENCES}

Bergström, S. M. Stratigraphic significance of Middle Ordovician bentonites in eastern and central North America // Appal. Bas. Industr. Assoc., 1982, N 2, 79-100.

Bergström, S. M., Nilsson, R. Age and correlation of the Middle Ordovician bentonites on Bornholm // Geol. Soc. Denmark, Bull., 1974, 23, 27-48.

Finney, S. C., Skevington, D. A mixed Atlantic-Pacific province Middle Ordovician graptolite fauna in western Newfoundland // Can. J. Earth Sci., 1979, 16, 18991902.

Kay, M. Distribution of Ordovician altered volcanic materials and related clays // Geol. Soc. Am. Bull., 1935, 46, 225-244.

Kolata, D. R., Frost, J. K., Huff, W. D. K-bentonites of the Ordovician Decorah Subgroup, Upper Mississippi Valley: Correlation by chemical fingerprinting // Illinois Geol. Surv. Circ., 1986, N 537, 1-30.

Kunk, M. J., Sutter, J. F., Bergström, S. M. ${ }^{40} \mathrm{Ar}-{ }^{39} \mathrm{Ar}$ age spectrum dating of biotite and sanidine from Middle Ordovician bentonites of Sweden: a comparison with results from eastern North America // Geol. Soc. Am. Abstr. Programs, 1984, 16, N 6, 566.

Laurence, $R$. A. An early Ordovician sinkhole deposit of volcanic ash and fossiliferous sediments in east Tennessee // J. Geol., 1944, 52, 235-249.

Sweet, W. C. Graphic correlation of upper Middle and Upper Ordovician rocks, North American Midcontinent // Palaeont. Contr. Univ. Oslo, 1984, N 295, 23-25.

Sweet, W. C. Mohawkian and Cincinnation chronostratigraphy // New York State Mus. Bull., 1988, N 462, 84-90.

\section{Ohio State University}

\section{S. M. BERGSTROM}

\section{GRAAFILISE KORRELATSIOONI KASUTAMISEST ORDOVIITSIUMI K-BENTONIITIDE SUNDMUSSTRATIGRAAFILISE TÄHTSUSE JA TRANSATLANTILISTE SUHETE SELGITAMISEL}

K-bentoniitide maksimaalne levik nii Põhja-Ameerikas kui ka Skandinaavias langeb keskordoviitsiumi teise poolde. Graafilise meetodiga on näidatud, et kõige markantsemad bentoniidikihid esinevad mőlemal pool ookeani praktiliselt ühel tasemel. See osutab nende suurele potentsiaalile sündmusstratigraafilisel korrelatsioonil.

\section{M. БЕРГСТРЕМ}

\section{ИСПОЛЬЗОВАНИЕ МЕТОДА ГРАФИЧЕСКОИ КОРРЕЛЯЦИИ ПРИ ОЦЕНКЕ ЗНАЧЕНИЯ К-БЕНТОНИТОВ В СОБЫТИЙНЙ СТРАТИГРАФИИ И ТРАНС- АТЛАНТИЧЕСКОЙ КОРРЕЛЯЦИИ}

Максимальное распространение К-бентонитов как в Северной Америке, так и в Скандинавин падает на вторую половину среднего ордовика. При помощи графической корреляции установлено, что наиболее мощные слон бентонитов на обонх берегах океана находятся примөрно на одном уровне. Это открывает большие возможности для коррелирования нх на событийной основе. 